\title{
Uncommon renal perihilar extramedullary haemopoiesis causing renal impairment
}

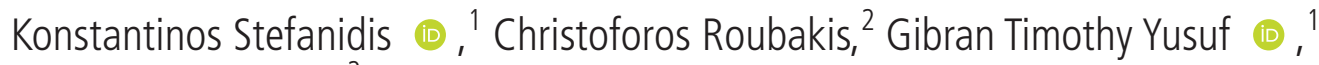 \\ Anastasia Tsakiridou ${ }^{2}$
}

'Radiology, King's College Hospital NHS Foundation Trust, London, UK

${ }^{2}$ Haematology, Metaxa Cancer Hospital of Piraeus, Piraeus, Greece

\section{Correspondence to}

Dr Konstantinos Stefanidis; kstefanidis@nhs.net

Accepted 24 June 2021
Check for updates

(c) BMJ Publishing Group Limited 2021. No commercial re-use. See rights and permissions. Published by BMJ.

To cite: Stefanidis $K$ Roubakis C, Yusuf GT, et al. BMJ Case Rep

2021;14:e242782

doi:10.1136/bcr-2021-

242782

\section{DESCRIPTION}

A 74-year-old man with myelofibrosis on the background of myelodysplastic syndrome/myeloproliferative neoplasm was admitted for progressive decline of the renal function and progressive tiredness. CT of the abdomen was performed showing a soft tissue lesion seeming to encase the left renal hilum and proximal left ureter with mild dilatation of the pelvicalyceal system and no hydroureter (figure 1A). Splenomegaly was also seen in keeping with the known background of myelofibrosis (figure 1A). An 18 F-fluorodeoxyglucose positron emission tomography (PET)/CT was requested to further characterise the parapelvic lesion showing no metabolic activity (figure 1B). An uncomplicated CT-guided biopsy was performed of the left parapelvic lesion with administration of contrast and a delayed excretory phase in order to visualise the proximal ureter and avoid inadvertent puncture (figure 1C-E). Typical trilineage haematopoiesis was histologically identified in the biopsy. The patient was treated with azacytidine and blood transfusions.

Extramedullary haemopoiesis (EMH) is the production of blood elements outside of the normal location in response to insufficient erythrogenesis by the bone marrow. It is usually secondary to insufficient production of blood elements due to replacement and infiltration of the bone marrow, most commonly caused by myelofibrosis, diffuse metastatic disease and leukaemia or insufficient quality of blood products most commonly in sickle cell anaemia and thalassaemia. ${ }^{1}$ Extramedullary haematopoiesis usually affects reticuloendothelial organs like liver, spleen, lymph nodes and thorax. It usually presents with visceromegaly and specifically with hepatosplenomegaly. The most common manifestation of EMH in the chest is paraspinal masses, usually associated with thalassaemia. ${ }^{1}$ Renal involvement is usually rare $^{2}$ and, when present, most commonly presents with perirenal soft tissue with retained renal contour. ${ }^{2} \mathrm{EMH}$ has also been reported with diffuse enlargement of the kidney and multifocal, small, hypodense lesions within the renal parenchyma causing generalised renal enlargement. ${ }^{3}$ There are only a few cases reports in the literature describing a soft tissue lesion encasing the renal hilum similarly to our case report. ${ }^{4-6}$ EMH can be hypermetabolic on PET/CT; ${ }^{6}$ however, in our case report, there was no metabolic activity and therefore justifies the need for biopsy. The most important clinical consequence is that EMH involving the kidneys may lead to renal failure, due to either ureteric obstruction or extensive parenchymal involvement. ${ }^{7}$ Biopsy is often necessary to exclude lymphoma which can also have a similar appearance. However, EMH

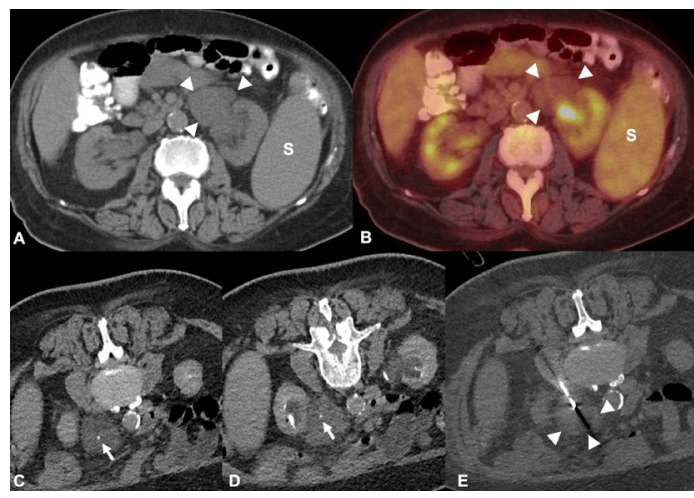

Figure 1 (A) Axial unenhanced CT image shows a left parapelvic soft tissue lesion (arrowheads) causing mild pelvicalyceal dilatation. Splenomegaly $(S)$ is also shown. (B) Axial positron emission tomography CT image at the same level. The left parapelvic soft tissue lesion (arrowheads) shows no metabolic activity. (C, D) CT-guided planning after intravenous administration of contrast agent. Delayed phase showing the soft tissue perihilar mass encasing the left ureter (arrow). (E) CT guided-biopsy of the perihilar mass. The tip of the biopsy needle is placed within the soft tissue mass (arrowheads).

deposits have a high tendency to haemorrhage given their vascular nature, therefore careful planning prior to any biopsy attempt is important. Treatment options for EMH include radiation therapy, excisional biopsy and frequent blood transfusions to limit haematopoietic stimulus. ${ }^{1}$

Contributors Identified the case: KS, CR and AT. Conception and design: KS, CR, GTY and AT. Literature search: KS. Drafting the manuscript: KS. Revising the manuscript critically for important intellectual content: KS, CR, GTY and AT. Final approval of the version to be published: $\mathrm{KS}, \mathrm{CR}$, GTY and AT.

\section{Learning points}

- Extramedullary haemopoiesis (EMH) with renal involvement is uncommon and especially in the perihilar location is an extremely rare condition, which can lead to renal impairment.

- Recognition of the renal perihilar parapelvic and vascular development of haematopoietic tissue is important to avoid any unnecessary biopsy, which can lead to complications and haemorrhage.

- The non-specific and rare CT findings of EMH should be suspected, particularly in patients with known risk factors. 
Images in...

Funding The authors have not declared a specific grant for this research from any funding agency in the public, commercial or not-for-profit sectors.

Competing interests None declared.

Patient consent for publication Obtained.

Provenance and peer review Not commissioned; externally peer-reviewed.

\section{ORCID iDs}

Konstantinos Stefanidis http://orcid.org/0000-0001-6127-1523

Gibran Timothy Yusuf http://orcid.org/0000-0002-5621-4249

\section{REFERENCES}

1 Georgiades CS, Neyman EG, Francis IR, et al. Typical and atypical presentations of extramedullary hemopoiesis. AJR Am J Roentgenol 2002:179:1239-43.
2 Roberts AS, Shetty AS, Mellnick VM, et al. Extramedullary haematopoiesis: radiological imaging features. Clin Radiol 2016;71:807-14.

3 Kopecky KK, Moriarty AT, Antony AC, et al. Extramedullary hematopoiesis in acute lymphocytic leukemia masquerading as hepatic, renal, and splenic microabscesses. AJR Am J Roentgenol 1986;147:846-7.

4 Tuite MJ, Weiss SL. Ultrasound and computed tomographic appearance of extramedullary hematopoiesis encasing the renal pelvis. J Clin Ultrasound 1991;19:238-40.

5 Gryspeerdt S, Oyen R, Van Hoe L, et al. Extramedullary hematopoiesis encasing the pelvicalyceal system: CT findings. Ann Hematol 1995;71:53-6.

6 Ricci D, Mandreoli M, Valentino M, et al. Extramedullary haematopoiesis in the kidney. Clin Kidney J 2012;5:143-5.

7 Woodward N, Ancliffe P, Griffiths MH, et al. Renal myelofibrosis: an unusual cause of renal impairment. Nephrol Dial Transplant 2000;15:257-8.

Copyright 2021 BMJ Publishing Group. All rights reserved. For permission to reuse any of this content visit https://www.bmj.com/company/products-services/rights-and-licensing/permissions/

BMJ Case Report Fellows may re-use this article for personal use and teaching without any further permission.

Become a Fellow of BMJ Case Reports today and you can:

- Submit as many cases as you like

- Enjoy fast sympathetic peer review and rapid publication of accepted articles

- Access all the published articles

Re-use any of the published material for personal use and teaching without further permission

\section{Customer Service}

If you have any further queries about your subscription, please contact our customer services team on +44 (0) 2071111105 or via email at support@bmj.com.

Visit casereports.bmi.com for more articles like this and to become a Fellow 